ISSN 2413-0877 Volume 2 (2015) 348-353

The 3rd International Conference on Biological Science

2013 (The 3rd ICBS-2013)

\title{
GROWTH AND AERENCHYMA FORMATION OF RICE (Oryza sativa L.) CV. IR64 AND INPARA 5 AT DIFFERENT INUNDATION CONDITIONS
}

\author{
Diah Rachmawati ${ }^{1 *}$, Maryani², Winda Adipuri Ramadaningrum and \\ Ika Nugrahaning Pratiwi \\ ${ }^{1}$ Laboratory of Plant Physiology, Faculty of Biology, Universitas Gadjah Mada Yogyakarta \\ ${ }^{2}$ Laboratory of Plant Structure and Development, Faculty of Biology, Universitas Gadjah Mada Yogyakarta \\ Correspondence author: diahbudiharjo@gmail.com
}

\begin{abstract}
Global climate change leads to changes in rainfall patterns, making it difficult to predict the occurrence of drought or flooding. Flooding had a negative impact on the rice growth. The objectives of this research were to study growth and aerenchyma formation of rice (Oryza sativa L.) cv. IR64 and Inpara 5 at different inundation conditions. This research was conducted in the greenhouse, Faculty of Biology, UGM from March to December 2012. Experiment design used was completely randomized design with factorial pattern of depth and period of inundation. Depth of inundation consists of 4 levels: $\mathrm{T} 0=0 \mathrm{~cm}, \mathrm{~T} 1=4 \mathrm{~cm}, \mathrm{~T} 2=8 \mathrm{~cm}$, and T3 $=12 \mathrm{~cm}$ from the soil surface, while the period of inundation consists of 3 levels, i.e. P1 $=10$ days inundation on the vegetative phase, $\mathrm{P} 2=10$ days inundation on the reproductive phase, and $\mathrm{P} 3=10$ days inundation on the vegetative and reproductive phase. The parameters observed were plant height, flowering time, soluble sugar and starch content in leaf, root anatomical structure. Data analysis was carried out by ANOVA and the differences between treatments were compared using DMRT at significancy level of $95 \%$. The results showed that IR64 and Inpara 5 respond differently to inundation. Depth of inundation had no effect on plant height of both IR64 and Inpara 5, while the inundation period showed a significant effect on plant height of Inpara 5. Inundation at vegetative phase increased plant height of Inpara 5. Both IR64 and Inpara 5, depth of inundation increased number of tillers and root aerenchyma formation, whereas period of inundation had no effect. Inundation treatment caused earlier flowering and stabilized soil pH. Starch content in leaf of Inpara 5 increased with inundation, while in IR64 decreased.
\end{abstract}

Key words : growth, aerenchyma, inundation, Inpara 5, starch

\section{INTRODUCTION}

Rice is generally resistant to inundation, but if the inundation exceeds the threshold pool cause impaired growth and development that will ultimately reduce productivity. Most of the rice cultivars showing stem elongation in response to flooding/inundation. Inundation at various depths and durations are the principal environmental cause of a shortage of oxygen $\left(\mathrm{O}_{2}\right)$ in plants. Stem elongation during a flooding is avoidance strategies (escape strategy) that enables rice plants to perform aerobic metabolism and $\mathrm{CO}_{2}$ fixation by the stem to the water surface (Vriezen et al., 2003; Sarkar et al., 2006). In addition, Inundation also induces adventitious root formation in the presence of ethylene which also facilitates the formation of aerenchyma (Vriezen et al., 2003).

Inundation effects are complex and vary depending on genotype, carbohydrate status before and after the inundation, development stage of the plant when inundation occurs, the level and duration of inundation and degree of water turbidity (Jackson and Ram, 2003; Das et al., 2005). Morphologically and physiologically, the inundation effect can be characterized by leaf chlorosis, stunted growth, and the death of the whole plant tissue (Vriezen et al., 2003). According Dat et al. (2004), the response shown in plants in inundation conditions

ISSN 2413-0877 (C) 2015 The Authors.

Published by KnowledgeE Publishing Services This is an open access article under the CC BY-NC-ND license (http://creativecommons.org/licenses/by-nc-nd/4.0)

Selection and Peer-review under responsibility of the 3rd ICBS-2013

Doi http://dx.doi.org/10.18502/kls.v2i1.172 
such lenticels hypertrophic, adventitious root and aerenchyma formation. The main character of morphology, physiology, and biochemistry of tolerant rice are slow leaves expansion, low levels of chlorosis, and carbohydrates accumulation during inundation (Kawano et al., 2009).

The objectives of this research were to study growth and aerenchyma formation of rice (Oryza sativa L.) cv. IR64 and Inpara 5 at different inundation conditions. Inundation of crops for varying duration and depth occurs at different growth stages resulting in unpredictable yield losses. Inundation-induced internode elongation and the maximum length that adult plants can reach varies amongst the different rice cultivars (Das et al., 2006). Inpara 5 known as rice tolerant to inundation during the vegetative phase of 14 days and have a shorter life than other cultivars (Agricultural Research, 2011), while the IR64 is widely cultivated rice cultivars in Indonesia, but not tolerant to inundation.

\section{MATERIALS AND METHODS}

The experiment was conducted using rice (Oryza sativa L. cv. IR64 and Inpara 5). The experiment was conducted in the greenhouse, Faculty of Biology, UGM from March to December 2012. Experiment design used was completely randomized design with factorial pattern of depth and period of inundation. Depth of inundation consists of 4 levels: T0 $0 \mathrm{~cm}$, $\mathrm{T} 1=4 \mathrm{~cm}, \mathrm{~T} 2=8 \mathrm{~cm}$, and $\mathrm{T} 3=12 \mathrm{~cm}$ from the soil surface, while the period of inundation consists of 3 levels, i.e. $\mathrm{P} 1=10$ days inundation on the vegetative phase, $\mathrm{P} 2=10$ days inundation on the reproductive phase, and P3 $=10$ days inundation on the vegetative and reproductive phase.

Rice seeds were sown in tray containing a mixture of soil and farmyard manure in a 3:1 ratio. Fourteen day-old seedlings were transplanted (two seedlings per pot) in circular plastic pots (30 cm height and $24 \mathrm{~cm}$ diameter) contaning $3 \mathrm{~kg}$ of soils. Ten days after transplanting, plants were thinned to 1 seedlings per pot. Plant then were subjected to different depth and period of inundation. Depth of inundation was maintained at 0, 4, 8 and $12 \mathrm{~cm}$ from the soil surface in different growth stages. The period inundation treatment were (P1) 10 days inundation at the vegetative phase; (P2) 10 days inundation at the reproductive phase; and (P3) 10 days inundation at the vegetative and reproductive phase. After inundation treatment, the availability of water during the rice growth were maintained at field capacity conditions.

The observed parameters were plant height, flowering age, soluble sugar and starch content in leaf, and root anatomical structure. Plant height were observed every week. Analysis of soluble sugars and starch leaves carried by anthrone method (Yoshida et al., 1976). Root preparations were made using the method of paraffin embedding. Data analysis was carried out by ANOVA and the differences between treatments were compared using DMRT at significancy level of $95 \%$.

\section{RESULTS AND DISCUSSION}

\section{a. Plant height}

Inundation affect plant growth and productivity. The effect of inundation depends on growth phase when inundation occurs, depth and duration of inundation. Growth of plant height as 
an indicator to determine the response of rice cultivars IR64 and Inpara 5 at different inundation conditions.

Depth of inundation did not affect plant height of rice (Oryza sativa L.) cv. Inpara 5 and IR64, while the treatment of inundation period showed significant effect on plant height of Inpara 5 (Table 1 \& 2). Inundation treatment at vegetative phase increased plant height of Inpara 5. Both Inpara and IR64, depth of inundation significantly increased root aerenchyma formation, but period of inundation did not significant effect.

Table 1. Plant height of rice (Oryza sativa L.) cv. IR64 at different depth and period of inundation at 12 weeks old

\begin{tabular}{|c|c|c|c|c|c|c|}
\hline \multirow{2}{*}{ Cultivars } & \multirow{2}{*}{$\begin{array}{l}\text { Period of } \\
\text { inundation }\end{array}$} & \multicolumn{4}{|c|}{ Depth of inundation } & \multirow{2}{*}{ Average } \\
\hline & & TO & $\mathrm{T} 1$ & $\mathrm{~T} 2$ & T3 & \\
\hline \multirow{4}{*}{ IR64 } & $\mathrm{P} 1$ & $74,96^{a}$ & $75,00^{a}$ & $75,30^{a}$ & $78,00^{a b}$ & $75,81^{p}$ \\
\hline & $\mathrm{P} 2$ & $74,96^{a}$ & $75,70^{a}$ & $80,50^{a b}$ & $77,70^{a b}$ & $77,21^{p}$ \\
\hline & P3 & $74,96^{\mathrm{a}}$ & $83,33^{a b}$ & $84,90^{b}$ & $78,70^{a b}$ & $80,47^{p}$ \\
\hline & Average & $74,96^{x}$ & $78,01^{x}$ & $80,23^{x}$ & $78,13^{x}$ & - \\
\hline
\end{tabular}

Means within the column and row followed by different letters differ significantly at the $5 \%$ probability level DMRT

Table 2. Plant height of rice (Oryza sativa L.) cv. Inpara 5 at different depth and period of inundation at 12 weeks old

\begin{tabular}{ccccccc}
\hline \multirow{2}{*}{ Cultivars } & $\begin{array}{c}\text { Period of } \\
\text { inundation }\end{array}$ & \multicolumn{5}{c}{ Depth of inundation } \\
\cline { 3 - 6 } & P1 & TO & T1 & T2 & T3 & \\
\hline \multirow{4}{*}{ Inpara 5 } & $90,58^{\mathrm{a}}$ & $95,02^{\mathrm{a}}$ & $94,26^{\mathrm{a}}$ & $96,16^{\mathrm{a}}$ & $95,15^{\mathrm{a}}$ \\
& P2 & $90,58^{\mathrm{a}}$ & $89,14^{\mathrm{a}}$ & $92,44^{\mathrm{a}}$ & $91,42^{\mathrm{a}}$ & $91,00^{\mathrm{p}}$ \\
& P3 & $90,58^{\mathrm{a}}$ & $93,12^{\mathrm{a}}$ & $92,80^{\mathrm{a}}$ & $88,66^{\mathrm{a}}$ & $91,53^{\mathrm{p}}$ \\
& Average & $90,58^{\mathrm{x}}$ & $92,43^{\mathrm{x}}$ & $93,17^{\mathrm{x}}$ & $92,08^{\mathrm{x}}$ & - \\
\hline
\end{tabular}

Means within the column and row followed by different letters differ significantly at the

$5 \%$ probability level DMRT

\section{b. Flowering Time}

The longer inundation, it will shorten the life of flowering rice plants. While the water depth variation showed no significant differences in time of flowering rice plants. Inundation treatment for 10 days at vegetative and reproductive phase showed earlier flowering. In the treatment of depth of inundation there was no significant differences in flowering time.

On IR64, Inundation treatment at vegetative and reproductive phases with $12 \mathrm{~cm}$ water depth (T3P3) of had the most rapid flowering age compared with other treatments (Table 3). Inundation period showed significant difference between the vegetative and reproductive (P3) and vegetative (P1). Inundation treatment caused earlier flowering

Table 3. Flowering age of rice (Oryza sativa L.) cv. IR64 at different depth and period of inundation

\begin{tabular}{|c|c|c|c|c|c|c|}
\hline \multirow{2}{*}{ Cultivars } & \multirow{2}{*}{$\begin{array}{l}\text { Period of } \\
\text { inundation }\end{array}$} & \multicolumn{4}{|c|}{ Depth of inundation } & \multirow{2}{*}{ Average } \\
\hline & & T0 & $\mathrm{T} 1$ & T2 & T3 & \\
\hline \multirow{4}{*}{ IR64 } & $\mathrm{P} 1$ & $58,67^{a b}$ & $59,67^{b}$ & $60,00^{b}$ & $59,33^{a b}$ & $59,42^{y}$ \\
\hline & $\mathrm{P} 2$ & $58,67^{\mathrm{ab}}$ & $59,33^{\mathrm{ab}}$ & $59,67^{b}$ & $59,00^{a b}$ & $59,17^{x y}$ \\
\hline & P3 & $58,67^{\mathrm{ab}}$ & $58,33^{\mathrm{ab}}$ & $59,00^{\mathrm{ab}}$ & $57,00^{a}$ & $58,25^{x}$ \\
\hline & Average & $58,67^{x}$ & $59,11^{x}$ & $59,56^{x}$ & $58,44^{x}$ & + \\
\hline
\end{tabular}

Means within the column and row followed by different letters differ significantly at the $5 \%$ probability level DMRT 
Table 4. Flowering age of rice (Oryza sativa L.) cv. Inpara 5 at different depth and period of inundation

\begin{tabular}{|c|c|c|c|c|c|c|}
\hline \multirow{2}{*}{ Cultivars } & \multirow{2}{*}{$\begin{array}{l}\text { Period of } \\
\text { inundation }\end{array}$} & \multicolumn{4}{|c|}{ Depth of inundation } & \multirow{2}{*}{ Average } \\
\hline & & T0 & $\mathrm{T} 1$ & $\mathrm{~T} 2$ & T3 & \\
\hline \multirow{4}{*}{ Inpara 5} & $\mathrm{P} 1$ & $64,8^{c}$ & $63,4^{\mathrm{bc}}$ & $62,4^{a b c}$ & $64,6^{c}$ & $63,5^{\text {qr }}$ \\
\hline & $\mathrm{P} 2$ & $64,8^{c}$ & $62,6^{a b c}$ & $60,4^{a}$ & $60,8^{a b}$ & $61,3^{p}$ \\
\hline & P3 & $64,8^{c}$ & $61,6^{\mathrm{ab}}$ & $61,2^{a b}$ & $63,0^{a b c}$ & $61,9^{\mathrm{pq}}$ \\
\hline & Average & $64,8^{y}$ & $62,5^{x y}$ & $61,3^{x}$ & $62,8^{x y}$ & + \\
\hline
\end{tabular}

\section{c. Aerenchyma formation}

Both Inpara and IR64, depth of inundation significantly increased root aerenchyma formation (Table $5 \& 6$ ). The percentage cortex to be aerenchyma also increased compared to control. However, period of inundation did not significant effect on IR64. In the flooded conditions, plants have a mechanism to prevent the loss of oxygen in the flooded area by forming aerenchyma (De Souza et al., 2009). According Vasellati et al. (2001), inundation will increase the aerenchyma tissue on the root cortex. Aerenchyma is parenchymal tissue with large intercellular space which has a function as a transport pathway gases such as ethylene, methane, oxygen and carbon dioxide. With the aerenchyma structure, oxygen can be easily transported from the roots to the stems under water.

Table 5. Percentage of cortex to be aerenchyma of rice (Oryza sativa L.) cv. IR64 at different depth and period of inundation

\begin{tabular}{ccccccc}
\hline \multirow{2}{*}{ cultivars } & $\begin{array}{c}\text { Period of } \\
\text { inundation }\end{array}$ & \multicolumn{4}{c}{ Depth of inundation } & \multirow{2}{*}{ Average } \\
\cline { 3 - 6 } & T0 & T1 & T2 & T3 & \\
\hline \multirow{4}{*}{ IR64 } & $48,74^{\text {a }}$ & $74,50^{\mathrm{b}}$ & $96,90^{\mathrm{d}}$ & $96,94^{\mathrm{d}}$ & $79,27^{\mathrm{x}}$ \\
& P2 & $75,00^{\mathrm{b}}$ & $100,00^{\mathrm{d}}$ & $85,00^{\mathrm{bc}}$ & $83,33^{\mathrm{bc}}$ & $85.83^{\mathrm{x}}$ \\
& P3 & $75,00^{\mathrm{b}}$ & $96,67^{\mathrm{cd}}$ & $95,00^{\mathrm{cd}}$ & $90,00^{\mathrm{bc}}$ & $89.17^{\mathrm{x}}$ \\
& Average & $66,25^{\mathrm{p}}$ & $90,39^{\mathrm{q}}$ & $92,30^{\mathrm{a}}$ & $90,09^{\mathrm{q}}$ & + \\
\hline
\end{tabular}

Means within the column and row followed by different letters differ significantly at the $5 \%$ probability level DMRT.

Table 6. Percentage of cortex to be aerenchyma of rice (Oryza sativa L.) cv. Inpara 5 at different depth and period of inundation

\begin{tabular}{lcccccc}
\hline \multirow{2}{*}{ cultivars $\begin{array}{c}\text { Period of } \\
\text { inundation }\end{array}$} & \multicolumn{5}{c}{ Depth of inundation } & \multirow{2}{*}{ Average } \\
\cline { 2 - 6 } & P1 & $40,33^{\mathrm{a}}$ & $73.00^{\mathrm{b}}$ & $72,33^{\mathrm{b}}$ & $93.33^{\mathrm{c}}$ & $69,74^{\mathrm{x}}$ \\
\multirow{3}{*}{ Inpara 5 } & $\mathrm{P} 2$ & $69.29^{\mathrm{b}}$ & $100.00^{\mathrm{c}}$ & $100.00^{\mathrm{c}}$ & $86.94^{\mathrm{bc}}$ & $89.33^{\mathrm{y}}$ \\
& $\mathrm{P} 3$ & $69.29^{\mathrm{b}}$ & $85.24^{\mathrm{bc}}$ & $97.50^{\mathrm{c}}$ & $97.67^{\mathrm{c}}$ & $87.42^{\mathrm{y}}$ \\
& Average & $60,97^{\mathrm{p}}$ & $86.08^{\mathrm{a}}$ & $89.94^{\mathrm{q}}$ & $92.64^{\mathrm{q}}$ & + \\
\hline
\end{tabular}

\section{d. Soluble sugar and starch}

On Inpara 5, leaf soluble sugar content showed similar results in the depth inundation treatment and control (Table 8). This suggests that the inundation did not cause changes in soluble sugar content in the leaves. Whereas in IR64 leaf soluble sugar content of the depth 
inundation treatment was different from control (Table 7). The leaf soluble sugar was decreased by increasing the depth of inundation. This can occur because of the possibility of sampling was conducted after 10 days of flooding treatment. At that time, the plant began to adapt to the aerial environment after a period of inundation is complete, and the accumulation of starch began to be broken down again into simple sugars.

Table 7. Soluble sugar content in the leaf of rice (Oryza sativa L.) cv. IR64 at different depth and period of inundation

\begin{tabular}{|c|c|c|c|c|c|c|}
\hline \multirow{2}{*}{ cultivars } & \multirow{2}{*}{$\begin{array}{l}\text { Period of } \\
\text { inundation }\end{array}$} & \multicolumn{4}{|c|}{ Depth of inundation } & \multirow{2}{*}{ Average } \\
\hline & & T0 & T1 & $\mathrm{T} 2$ & T3 & \\
\hline \multirow{4}{*}{ IR64 } & P1 & $184,07^{c}$ & $103,92^{b}$ & $56,52^{a b}$ & $44,23^{a}$ & $97,19^{p}$ \\
\hline & $\mathrm{P} 2$ & $62,06^{\mathrm{ab}}$ & $40,56^{a}$ & $54,28^{a b}$ & $53,06^{a b}$ & $52,49^{q}$ \\
\hline & P3 & $62,06^{a b}$ & $49,06^{a b}$ & $29,07^{a}$ & $37,45^{a}$ & $44,41^{\mathrm{q}}$ \\
\hline & Average & $102,73^{y}$ & $64,51^{x}$ & $46,62^{x}$ & $44,91^{x}$ & + \\
\hline
\end{tabular}

Means within the column and row followed by different letters differ significantly at the $5 \%$ probability level DMRT.

Table 8. Soluble sugar content in the leaf of rice (Oryza sativa L.) cv. Inpara 5 at different depth and period of inundation

\begin{tabular}{|c|c|c|c|c|c|c|}
\hline \multirow{2}{*}{ cultivars } & \multirow{2}{*}{$\begin{array}{l}\text { Period of } \\
\text { inundation }\end{array}$} & \multicolumn{4}{|c|}{ Depth of inundation } & \multirow{2}{*}{ Average } \\
\hline & & T0 & T1 & T2 & T3 & \\
\hline \multirow{4}{*}{ Inpara 5} & $\mathrm{P} 1$ & $105,82^{a b}$ & $131,00^{\text {ab }}$ & $129,64^{a}$ & $114,73^{a}$ & $86,84^{p}$ \\
\hline & P2 & $99,49^{a b}$ & $60,00^{a}$ & $164,64^{\mathrm{c}}$ & $140,63^{b c}$ & $121,76^{p q}$ \\
\hline & P3 & $99,49^{a b}$ & $59,54^{a}$ & $107,69^{a b}$ & $68,15^{\mathrm{a}}$ & $78,46^{p}$ \\
\hline & Average & $99,49^{x y}$ & $74,61^{x}$ & $119,23^{x y}$ & $93,22^{x y}$ & + \\
\hline
\end{tabular}

Means within the column and row followed by different letters differ significantly at the $5 \%$ probability level DMRT.

Depth of inundation increased starch content of the leaves of Inpara 5 (Table 10). Increased starch content in the leaves of plants in an effort to save energy, which can be used when conditions are not flooded. The existence of the energy savings, will use the plant to grow on the normal condition. The results showed that the inundation treatment will cause increased starch content of the leaves, as an energy storage efforts

Table 9. Starch content in the leaf of rice (Oryza sativa L.) cv. IR64 at different depth and period of inundation

\begin{tabular}{|c|c|c|c|c|c|c|}
\hline \multirow{2}{*}{ cultivars } & \multirow{2}{*}{$\begin{array}{l}\text { Period of } \\
\text { inundation }\end{array}$} & \multicolumn{4}{|c|}{ Depth of inundation } & \multirow{2}{*}{ Average } \\
\hline & & T0 & $\mathrm{T} 1$ & $\mathrm{~T} 2$ & T3 & \\
\hline \multirow{4}{*}{ IR64 } & $\mathrm{P} 1$ & $23,05^{a}$ & $20,47^{a}$ & $23,47^{a}$ & $22,61^{a}$ & $22,40^{p}$ \\
\hline & $\mathrm{P} 2$ & $51,33^{b}$ & $40,25^{\mathrm{ab}}$ & $23,38^{a}$ & $31,86^{a}$ & $36,70^{\mathrm{pq}}$ \\
\hline & P3 & $51,33^{b}$ & $56,35^{b}$ & $40,89^{a b}$ & $21,15^{a}$ & $42,43^{q}$ \\
\hline & Average & $41,90^{y}$ & $39,02^{x y}$ & $29,25^{x}$ & $25,21^{x}$ & + \\
\hline
\end{tabular}

Means within the column and row followed by different letters differ significantly at the $5 \%$ probability level DMRT. 
Table 10. Starch content in the leaf of rice (Oryza sativa L.) cv. Inpara 5 at different depth and period of inundation

\begin{tabular}{ccccccc}
\hline \multirow{2}{*}{ cultivars } & $\begin{array}{c}\text { Period of } \\
\text { inundation }\end{array}$ & \multicolumn{4}{c}{ Depth of inundation } & \multirow{2}{*}{ Average } \\
\cline { 3 - 6 } & P1 & T0 & T1 & T2 & T3 & \\
\hline \multirow{4}{*}{ Inpara 5 } & P2 & $4,92^{\mathrm{c}}$ & $16,96^{\mathrm{a}}{ }^{\mathrm{bc}}$ & $25,87^{\mathrm{c}}$ & $21,44^{\mathrm{c}}$ & $22,29^{\mathrm{a}}$ \\
& $\mathrm{P} 3$ & $4,96^{\mathrm{a}}$ & $3,58^{\mathrm{a}}$ & $21,50^{\mathrm{bc}}$ & $17,23^{\mathrm{bc}}$ & $11,65^{\mathrm{p}}$ \\
& Average & $11,61^{\mathrm{x}}$ & $7,81^{\mathrm{x}}$ & $21,74^{\mathrm{y}}$ & $15,97^{\mathrm{b}}$ & $10,59^{\mathrm{p}}$ \\
& & &
\end{tabular}

Means within the column and row followed by different letters differ significantly at the $5 \%$ probability level DMRT.

\section{CONCLUSION}

Summarizing the results obtained we could conclude that

1. Depth of inundation had no effect on plant height of both IR64 and Inpara 5, while the inundation period showed a significant effect on plant height of Inpara 5.

2. Period of Inundation treatment at vegetative and reproductive phase caused earlier flowering.

3. Depth of inundation increased root aerenchyma formation, whereas period of inundation had no effect.

\section{REFERENCES}

Das, K.K., R.K. Sarkar, and A.M. Ismail. 2005. Elongation ability and non-structural carbohydrate levels in relation to submergence tolerance in rice. Plant Science. 168:131-136. doi:10.1016/j.plantsci.2004.07.023

De Souza, T.C., E.M. de Castro, E.J. Pereira, S.N. Parentoni, and P.C. Magalhaens. 2009. Morpho-anatomical characterization of root reccurent selection cycles for flood tolerance of Maize (Zea mays L.). Plant Soil Environ 55 (11) : 504-510

Jackson, M.B. and P.C. Ram. 2003. Physiological and Molecular Basis Susceptibility and Tolerance of Rice Plants to Complete Submergence. Annals of Botany. 91: 227-241. doi:10.1093/aob/mcf242

Kawano, N., O. Ito, and J. Sakagami. 2009. Morphological and physiological response of rice seedlings to complete submergence (flash flooding). Annals of Botany . 103 : 161-169

Sarkar, R. K., J.N. Reddy, S.G. Sharma1, and A.M. Ismail. 2006. Physiological basis of submergence tolerance in rice and implications for crop improvement. Current Science. 91(7): 899-906.

Vriezen, W.M., Z. Zhou, and D. Van Der Straeten. 2003. Regulation of Submergence-induced Enhanced Shoot Elongation in Oryza sativa L. Annals of Botany. 91:263-270. doi: 10.1093/aob/mcf121.

Vasellati, V., M. Oesterheld, D. Medan, and J. Loreti. 2001. Effects of flooding and drought on the anatomy of Paspalum dilatatum. Annals of Botany. 88(3): 355-360

Yoshida, S., D. Forno, J. Cock, and K.A. Gomez. 1976. Laboratory Manual for Physiological Studies of Rice. IRRI. Los Banos, Philipines, pp.46-49. 